\title{
Pseudo-Panel Data Estimation of Japanese Tobacco Consumption
}

\author{
Phocenah Nyatanga (United Graduate School of Agriculture, Tottori University) \\ Toshinobu Matsuda (Faculty of Agriculture, Tottori University)
}

\author{
擬似パネルデータによるたばこ消費の推定 \\ フォセナ・ニャタンガ（鳥取大学大学院連合農学研究科） \\ 松田 敏信 (鳥取大学農学部)
}

\begin{abstract}
本稿の目的は, 月別・都市別に集計された擬 似パネルデータを用い,わが国のたばこ消費の 推定を行らことである.わが国のたばこ価格は, たばこ税増税にともなら価格改訂以外に変動が ないため, 通常の需要関数による分析は適切で ない，そこで，複雑な消費支出の変動を把握す るために，ワーキング・モデルを対数支出の 2 次関数に拡張したエンゲル曲線を推定した.さ らに時系列方向のダイナミックな変動をとらえ
\end{abstract}

\section{Introduction}

Cigarette consumption is an issue of concern, and for a significant number of years, the industry has been the focus of attention for many economists, public health advocates, and policy makers. The $2008 \mathrm{WHO}$ report on the global tobacco epidemic ranked smoking as one of the biggest preventable public health threat facing the world in the $21^{\text {st }}$ century. Because of its hazardous effect and health burden to society, many governments have adopted and continue to adopt policies to reduce tobacco consumption. The major intervention policies adopted by governments include high cigarette taxes, banning smoking in public places, advertisement restrictions, imposing healthwarning labels on cigarette packaging, promotion of antismoking campaigns, and increasing public health awareness. The effectiveness of such policies is a subject of debate. A significant number of researchers, among them Baltagi and Levin (1986), Chiloupka and Warner (2000), Duffy (2003), Brown (1995), Saffer and Chiloupka (2000), Selvanathan (2005), and Goel and Nelson (2006), have attempted to evaluate the effectiveness of these policies in different countries, and their findings have been remarkable. Our study seeks to contribute to this debate
るために誤差修正モデルとして定式化し，また 地域差をとらえるために固定効果モデルとして 推定した。分析の結果，たばこの需要は消費支 出の変動に対して極めて非弾力的で, 負のトレ ンドが観察された。また，たばこ税増税直前の 駆け込久需要による消費増加効果に対して, 増 税直後の消費減少効果は比較的小さかった。さ らに, いくつかの都市間には顕著な地域差が存 在することが明らかになった。

by assessing the effects of income, tax reform and other factors on tobacco consumption in Japan.

Worldwide, Japan is one of the countries with a very high smoking incidence. In a bid to reduce consumption, the Japanese government has adopted several policies, including high tax on cigarettes, a ban on product advertising, setting up of smoking areas in public places, promotion of programmes to increase public awareness of the harmful effects of smoking, and the recent 'Taspo' age verification initiative aimed at reducing underage smoking. The effectiveness of these policies has yet to be determined.

Cigarette consumption has several unique features that distinguish it from most other products. The addictive nature of the product tends to make its responsiveness less elastic to income and price changes, at least in the long run. Taking into account the dynamic long- and shortterm properties, our research adopts an Engel-curveerror-correction model, which is a quadratic extension of Working's model. This extension was found to fit better for analysing cigarette demand in Japan, given that cigarette price is fixed uniformly across all prefectures. Using a monthly pseudo-panel dataset for 49 cities, a fixed effect model was adopted to capture the difference in to- 
bacco demand among cities. On the basis of this functional form, we estimated expenditure elasticities and trend, tax, city, demographic, and monthly effects. We observed that cigarette consumption responds positively to expenditure changes although the smoking trend is negative and that tax increases were slightly effective in reducing consumption, both in the short and long term. Detailed findings are documented in section 4 of this paper.

\section{The Model}

Engel curves are important in expressing how the demand for a commodity changes as incomes vary, assuming fixed prices. Working (1943) proposed an Engel curve model expressed in the budget share form:

$$
w_{i}=\alpha_{i}+\beta_{i} \log Y \text {, }
$$

where $w$ is the share of income spent buying good $i, Y$ is income or total expenditure, and $\alpha$ and $\beta$ are the coefficients to be estimated. Engel's original work expresses the relevance of other consumer characteristics, such as age and household composition, in explaining cross-sectional variation in demand. Thus, our Engel curve is a quadratic extension of Working's model, expressed as follows:

$$
w=\alpha+\beta \log Y+\gamma(\log Y)^{2}+f(t, Z),
$$

where $t$ is the time trend and $Z$ is a vector of other characteristics of demand. Taking account of dynamic long- and short-term properties, we employ an error correction form, in which we estimate the expenditure elasticity of cigarettes as well as the effects of several demographic and dummy variables on consumption. This form is defined as the equation given below:

$$
\begin{aligned}
\Delta w_{t}= & \alpha_{1}^{S}+\sum_{i=1}^{4} \theta_{i}^{S} \Delta Z_{i t}+\sum_{j=1}^{17} \delta_{j}^{S} \Delta D_{j t} \\
& +\beta^{S} \Delta \log Y_{t}+\gamma^{S} \Delta\left(\log Y_{t}\right)^{2} \\
& +\lambda\left[\alpha_{0}^{L}+\alpha_{1}^{L}(t-1)+\sum_{i=1}^{4} \theta_{i}^{L} Z_{i, t-1}+\sum_{j=1}^{65} \delta_{j}^{L} D_{j, t-1}\right. \\
& \left.+\beta^{L} \log Y_{t-1}+\gamma^{L}\left(\log Y_{t-1}\right)^{2}-w_{t-1}\right]+\varepsilon_{t}^{S},
\end{aligned}
$$

where $Z_{1}$ to $Z_{4}$ are demographic variables (household size, number of persons under the age of eighteen, number of earners per household, and percentage who own their houses-'homeowners'); $D_{1}$ to $D_{11}$ are monthly dummy variables; $D_{12}$ to $D_{17}$ are the before and after tax reform dummy variables; $D_{18}$ to $D_{65}$ are regional dummy variables; $S$ is short term; $L$ is long term; $\alpha, \theta, \delta, \beta, \gamma$, and $\lambda$, are unknown parameters to be estimated; and $1 / \lambda$ is the adjustment period $(0<\lambda<1)$.

Our model is based on the theory of rational addiction, which argues that individuals make choices that extend over several time-periods, and addictive consumptions in different time-periods are complementary. The rational addiction model was initiated by Becker and Murphy (1988) and its application to cigarette demand was advanced by Chalaoupka (1991) as well as by Baltagi and Griffin (2001). Thus, the error correction model was chosen because it is more realistic given that its structure enables us to assess the short-term adjustment process as well as the long-term equilibrium.

We estimated the short- and long-term expenditure elasticities of demand evaluated at the sample mean for the quadratic Engel curve as equation (4) below.

$$
\begin{aligned}
E_{\text {term }} & =\frac{\partial Q_{t}}{\partial Y_{t}} \frac{Y_{t}}{Q_{t}}=1+\frac{1}{w_{t}} \frac{\partial w_{t}}{\partial \log t} \\
& =1+\frac{\beta^{\text {term }}+2 \gamma^{\text {term }} \log Y_{t}}{w_{t}}, \text { term }=L, S
\end{aligned}
$$

The trend effect and demographic effects were respectively calculated by equations (5) and (6).

$$
\begin{aligned}
& \frac{100}{Q_{t}} \frac{\partial Q_{t}}{\partial t}=\frac{100}{w_{t}} \frac{\partial w_{t}}{\partial t}=\frac{100 \alpha_{1}^{\text {term }}}{w_{t}} \\
& \frac{100}{Q_{t}} \frac{\partial Q_{t}}{\partial Z_{i t}}=\frac{100}{w_{t}} \frac{\partial w_{t}}{\partial Z_{i t}}=\frac{100 \theta_{i}^{\text {term }}}{w_{t}}
\end{aligned}
$$

These elasticities and effects vary with variable $w_{t}$ and $Y_{t}$ and were evaluated at the sample mean of $w_{t}$ and $Y_{t}$ respectively. Tax and seasonal effects were calculated in a similar manner as trend and demographic effects.

\section{The Data Set}

This study uses monthly pseudo-panel data for households of two or more people, for forty-nine cities, obtained from the Family Income and Expenditure Survey of Japan carried out by the Ministry of Internal Affairs and Communications from January 2000 through December 2008 (sample size of 5,292). Although this survey follows a consistent methodology, parts of the surveyed households changed periodically, making this pseudo-panel data not real panel data. ${ }^{1)}$ The expenditure data used in this analysis excluded durables and was seasonally unadjusted. Both expenditure on cigarettes and total expenditure were 
deflated using the monthly consumer price index (general). As the price of cigarettes only changed twice in the period analysed, (changes resulting from the tax hikes effective July 2003 and July 2006), our model makes use of various dummy variables (one month before the tax increase and two months following the increase) to capture the effect of these two price changes on consumption behaviour. To measure the city effects, we used city dummy variables, with Tokyo as the base city. Monthly dummy variables were also utilized to evaluate the consumption pattern at various time intervals, compared to December. Our study also includes several demographic variables that have a significant effect on consumption, to help explain cross-sectional variation in demand.

\section{Discussion of Estimated Results}

The short and long-term expenditure elasticities were estimated to be 0.21905 and 0.1698 , respectively, and highly significant, indicating that cigarette demand responds positively to expenditure changes. However, the trend effect was estimated to be significantly negative $(-0.1096 \%)$ in the long term, signifying an overall decline in cigarette consumption. Several theories such as wealth, education and changes in public opinion about smoking might explain why cigarette consumption exhibits such a trend. This result is consistent with the findings of Selvanathan (2005) who observed that smoking is on the decline in developed countries because of the increasing health awareness and the educational campaigns of antismoking advocates.

\section{(1) Tax effects}

Using dummy variables, we estimated the short- and long-term tax effects of the two tax reforms to be highly positive, and significant the month before the tax came into effect (see Table 1 below). As there is no quantity restriction on cigarette purchases at any given point, and cigarettes are a non-perishable product that can easily be stored, it is rational behaviour for consumers to respond to an anticipated tax increase by stocking up just before the actual increase comes into effect, thus explaining the positive effect. The short- and long-term tax effects of the two tax reforms were significantly negative two months following the tax imposition, with a short-term adjustment period of 2.89 months (88 days). However, although the tax effect was extremely negative for the first month following the tax changes, its effect was much smaller the second month and insignificant thereafter. On the basis of
Table 1. Estimated Long-term and Short-term Tax Effects

\begin{tabular}{lcc}
\hline \hline \multirow{2}{*}{ Variable } & \multicolumn{2}{c}{1 st tax reform } \\
\cline { 2 - 3 } & Long term & Short term \\
\hline \multirow{2}{*}{ Month before (D1) } & $60.710^{* * *}$ & $62.099 * * *$ \\
First month after (D2) & $(11.984)$ & $(18.838)$ \\
& $-28.619 * * *$ & $-26.572^{* * *}$ \\
Second month after (D3) & $-5.4386^{* *}$ & $(-6.981)$ \\
& $(-1.074)$ & $-2.8523^{* *}$ \\
\hline \hline \multirow{2}{*}{ Variable } & \multicolumn{1}{c}{$2 \mathrm{nd}$ tax reform } \\
\cline { 2 - 3 } & Long term & Short term \\
\hline \multirow{2}{*}{ Month before (D4) } & $59.740 * * *$ & $64.903^{* * *}$ \\
First month after (D5) & $(11.764)$ & $(19.693)$ \\
Second month after (D6) & $-34.594 * * *$ & $-27.471^{* * *}$ \\
& $(-6.813)$ & $(-7.2197)$ \\
\hline
\end{tabular}

Note: $\mathrm{i} . *$ when $\mathrm{p}$-value $\leq 0.1, * *$ when p-value $\leq 0.05$, and $* * *$ when p-value $\leq 0.01$.

ii. Values in parentheses are t-ratios

this analysis, we can conclude that overall, the two tax reforms made during the period of analysis had some effect in reducing consumption, though the effect diminished with time. Such consumption behaviour after the tax imposition could have been a result of the stocking-up before the tax came into effect. As the hoarded product ran out, those consumers had to revert to the market, thus reducing the tax effect. It can also be argued that the tax reforms were not high enough to exert sufficient pressure on consumers to drastically reduce consumption in the long term. Baltagi and Levin (1986) argued that cigarette taxation might deter cigarette consumption, but the effectiveness of this policy depends on the level of the price increase.

\section{(2) Demographic effects}

As far as demographic effects are concerned, we observed that household size had a significant and positive effect on consumption in the long term, (see Table 2 below). The same is true for the percentage of homeowners.

This result was anticipated given the financial burden of consumers in this category. The number of earners per household, however, had a positive and highly significant long- and short-term effect on consumption. A possible 
Table 2. Estimated Long-term and Short-term Demographic Effects

\begin{tabular}{ccc}
\hline \hline Variable & Long term & Short term \\
\hline \multirow{2}{*}{ Size } & $13.563 * *$ & -6.8726 \\
& $(2.053)$ & $(-0.847)$ \\
\multirow{2}{*}{ Under } & $-21.461^{* * *}$ & 3.1222 \\
& $(-3.002)$ & $(0.340)$ \\
Earner & $15.936^{* * * *}$ & $22.402^{* * *}$ \\
& $(2.774)$ & $(3.116)$ \\
Owner & $-0.48149 * * *$ & $-0.56701^{* * *}$ \\
& $(-5.974)$ & $(-4.795)$ \\
\hline
\end{tabular}

Note: Refer to the note of Table 1

explanation for this result could be the increase in the number of women working and smoking. Statistics show smoking to be on the increase among working women in Japan and worldwide. According to Surveys carried out annually by Japan Tobacco, more than twice as many women in their 20's now smoke compared to 1970.

\section{(3) Regional effects}

Regarding regional effects, we found twenty-seven out of forty-eight cities to have significant regional effects compared to Tokyo. Sapporo had the highest city effect of $96.51 \%$, followed by Kanazawa, Wakayama, Kita-Kyushu, and Kochi with $31.11 \%, 29.31 \%, 27.63 \%$, and $24.77 \%$

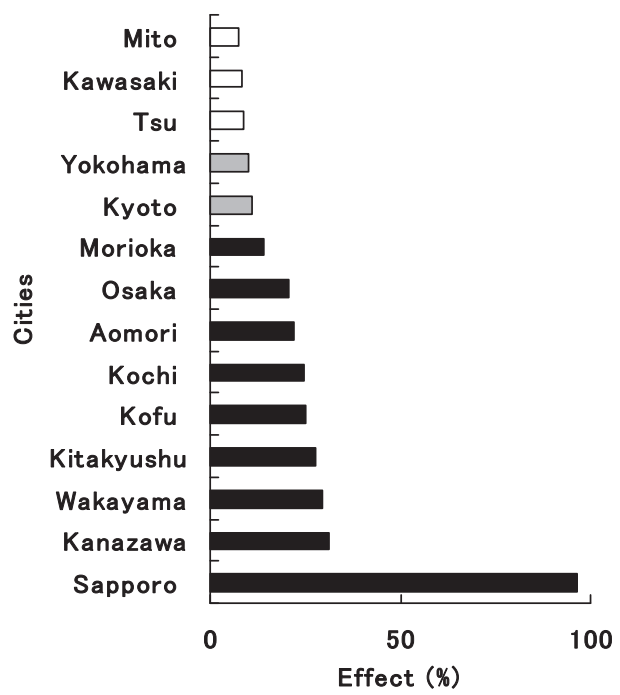

Fig. 1. Cities with Positive Statistically Significant City Effects

Note: $\square$ when p-value $\leq 0.1, \square$ when p-value $\leq 0.05$, and when p-value $\leq 0.01$.

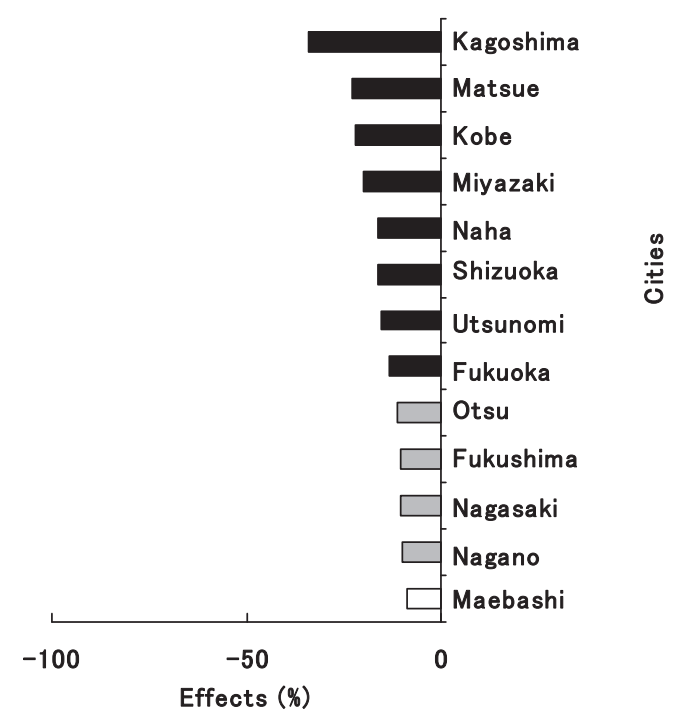

Fig. 2. Cities with Negative Statistically Significant City Effects

Note: Refer to the note of Fig. 1

respectively; while Kagoshima, Matsue and Kobe had negative and the lowest city effects of $-33.84 \%,-22.93 \%$ and $-21.97 \%$ respectively (see Fig. 1 and Fig. 2 below). It is not clear why Sapporo has such a high city effect. We can speculate that factors such as taste and weather difference between Tokyo and Sapporo could be possible explanations of such a huge discrepancy.

\section{(4) Seasonal effects}

Seasonal effects were found to be an insignificant influence on consumption, especially in the long term, except for the month of January, where they are significantly negative (see Table 3 below). In the short term, the seasonal effects were significant in January, August, and September only. Such a significant response during these periods can

Table 3. Estimated Long-term and Short-term Seasonal Effects

\begin{tabular}{lcc}
\hline \hline Variable & Long term & Short term \\
\hline \multirow{2}{*}{ January } & $-5.1918^{*}$ & $-3.3170^{* *}$ \\
& $(-1.948)$ & $(-2.265)$ \\
August & 4.3152 & $4.293^{* *}$ \\
& $(1.593)$ & $(2.008)$ \\
September & 2.8193 & $3.9602^{* *}$ \\
& $(1.043)$ & $(1.983)$ \\
\hline
\end{tabular}

Note: Refer to the note of Table 1 
be explained by the two major bonuses in July and December. However, in the long term, demand is not significantly influenced by such events.

\section{Conclusion}

Our research analysed the significance of tax reform policy, as well as the effect of several demographic variables and other factors on cigarette consumption. The aim was to determine how demand for tobacco is likely to change as expenditure changes, as well as to assess the impact of cigarette tax reform on demand. The estimation results show cigarette demand to be positively responsive to expenditure changes. However, the product faces negative trend effects. The two tax increases were found to be effective in reducing consumption, though the effect diminished with time. We also found tobacco consumption in fourteen cities to be significantly greater than in Tokyo, but significantly lower in thirteen cities, holding all other factors constant. Variables of household size, and earners per household were found to have a positive effect on consumption, whereas number of children under the age of eighteen and home ownership had some negative effect. Lastly, seasonal effects were found to be insignificant, both in the short and long term.

\section{Acknowledgements}

This research was supported by Grant-in-Aid for Scientific Research (B), no. 19380128, Japanese Ministry of Education, Culture, Sports, Science and Technology and Zengin Foundation for Studies on Economics and Finance.

\section{Note}

1) The use of real panel data is desirable in analysing the habitual aspect of smoking over time. However, such data is difficult to obtain, thus the use of pseudo-panel data. As pseudo-panel uses aggregated data, its use presents a limitation to our analysis in that we cannot adequately analyse the habitual aspect of smoking among different age groups over time.

\section{References}

[1] B. H. Baltagi, and D. Levin, "Estimating dynamic demand for cigarettes using panel data: The effects of bootlegging, taxation, and advertising reconsidered", Review of Economics and Statistics, Vol. 68, No. 1, (1986), pp. 148-155.

[2] B. H. Baltagi, and J. M. Griffin, "The Econometrics of Rational Addiction: The Case of Cigarettes", Journal of Business \& Economic Statistics, Vol. 19, No. 4 (2001), pp. 449-454.

[3] G. S. Becker, and K. M. Murphy, "A Theory of Rational Addiction”, Journal of Political Economy, Vol. 96, No. 4 (1988), pp. 675-700.

[4] B. A. Brown, "Cigarette taxes and smoking restrictions: Impacts and policy implications", American Journal of Agricultural Economics, Vol. 77, No. 4 (1995), pp. 946-951.

[5] F. J. Chaloupka, "Rational Addictive Behavior and Cigarette Smoking”, Journal of Political Economy, Vol. 99, No. 4 (1991), pp. 722-742.

[6] F. J. Chaloupka, and K. E. Warner, "The Economics of Smoking”, Handbook of Health Economics, Vol. 1, No. 1 (2000), pp. 1539-1627.

[7] M. Duffy, "Advertising and Food, Drink and Tobacco Consumption in the United Kingdom; A Dynamic Demand System", Agricultural Economics, Vol. 28, No. 1 (2003), pp. 51-70.

[8] R. K. Goel, and M. A. Nelson, "The Effectiveness of Anti-Smoking Legislation: A Review”, Journal of Economic Surveys, Vol. 20, No. 2 (2006), pp. 325-355.

[9] H. Saffer, and F. Chaloupka, "The Effect of Tobacco Advertising Bans on Tobacco Consumption”, Journal of Health Economics, Vol. 19, No. 6 (2000), pp. 1117 1137.

[10] S. Selvanthan, The Demand for Alcohol, Tobacco and Marijuana: International Evidence, Ashgate, (2005), pp. 1-396.

[11] H. Working, "Statistical Laws of Family Expenditure," Journal of the American Statistical Association, Vol. 38, No. 221 (1943), pp. 43-56. 